\title{
THE ORANG-UTAN CRISIS
}

\section{FOREWORD}

The Orang-utan or Maias, Pongo pygmaeus, which lives only in the islands of Borneo and Sumatra, is one of the animals in greatest danger of extermination throughout the world. The threat comes from the demand for young captive orangs. These are normally obtained by shooting the mother, so that, remembering also the numbers of baby orangs which must be killed accidentally with their mothers or die in transit later from disease or undernourishment, it is reasonable to estimate that for every orang to reach its final destination in captivity, at least three perish.

In articles in Oryx, VI, 2, August, 1962, Major Tom Harrisson, director of the Sarawak Museum, and his wife, Barbara Harrisson, brought the position of the Orang-utan vividly before the Fauna Preservation Society and for long before that the Society had been bringing the parlous state of the Orang-utan to the notice of the authorities in Singapore-for most orang-utans obtained in the wild are taken first to that port.

More recently, at a meeting of the Executive Board of IUCN in May, 1963, Dr. Harold Coolidge, Executive Director of the National Academy of Sciences, U.S.A., who had just returned from Singapore, told the writer that at least sixty orangs were then "in the pipeline. from Sumatra and Borneo to America and Europe". He suggested that another enquiry should be made at Singapore and this has resulted as follows :-

No orang may legally enter Singapore without an import licence and these licences are not granted without an export licence from the country of origin, but control of import is very difficult because of the vast number of ships entering the port and the fact that an orang may be kept on board, nominally as a sailor's pet, until an opportunity to smuggle it ashore occurs. There is no ban on the mere possession of orang-utans in Singapore but their export is illegal without an export licence. The activities of would-be exporters of smuggled orangs have also been hampered by recent action of the local Customs authority who have refused permits unless import licences could be shown. The old trick of exporting young orangs among batches of other monkeys has become too well known to be practicable.

The channel through which many orangs smuggled into Singapore have been re-exported was until recently directed through Bangkok. This channel has now been closed through the efforts of Dr. Boonsong Lekagul, member of the Executive Board of IUCN and of the Survival Service Commission. Beyond Singapore there are other possible transit ports for orangs. Of these an important one was Hong Kong but in 1962 it was decided that the special permit required for the import of orangs will only be issued on condition that the animals be accompanied by a health certificate signed by a recognized officer of the exporting country.

Another outlet for the orang traffic was thought to be Macao but the Portuguese governor has written that no importation of orangs has ever been registered there and that adequate measures will be taken to prevent such traffic. 
Now new outlets on the mainland of Asia for the traffic in illegally captured orang-utans are being sought. We are following up clues to their whereabouts.

As a result of the above difficulties of export the Singapore ring of dealers had about eighty-five orangs on their hands. Many orangs died and more may have been killed deliberately, for an orang costs at least one Malay dollar (2s. 4d.) to feed daily and this is more than most dealers are prepared to spend on a doubtful asset. Early in June, 1963, there were at least fifty orangs in Singapore, perhaps a good many more. The price had fallen to 150 to 200 Malay dollars each $(£ 20$ to $£ 25)$ for infants.

The International Union for the Conservation of Nature has directed its effort for the preservation of the Orang-utan into two projects, supported by the World Wildife Fund.

(1) The establishment of young orang-utans which have been confiscated or otherwise obtained under conditions which make their direct return to the wild impossible. The intention is to form a wild population from these captives. This part of the project is being carried out by Mrs. Barbara Harrisson at Bako National Park, Sarawak. Her report on the first year's working has been received and is given here in an abbreviated form. The full report will be published in the Sarawak Museum fournal. Mrs. Harrisson is also responsible for investigation of the orang situation in British Borneo.

(2) The investigation of the orang situation throughout South-East Asia (except British Borneo). This is being carried out by Mr. Oliver Milton whose investigation includes the status of the Sumatran rhinoceros. Mrs. Harrisson's and Mr. Milton's projects are complementary to one another.

That responsible zoos are taking the position of the orang-utan seriously and are very anxious for the survival of endangered species in the wild is shown by the following resolutions passed by the Board of Directors of the American Association of Zoological Parks and Aquariums at their meetings during September, 1962, and March, 1963:

"RESOLVED that in the interest of conservation, the Board of Directors of the American Association of Zoological Parks and Aquariums strongly recommend to the membership of the Association that all endangered species that are fully protected and adequately managed by their country, receive the additional protection which we can afford them by our refusal to purchase any wild-caught specimens of these species which are removed illegally from country of origin and subsequently offered for sale on the animal market."

"RESOLVED that the Board of Directors instruct the Conservation Committee to prepare, annually, a list of animals, whose wild population, in the Committee's judgment, would be seriously endangered by new zoo collection, importation and/or exhibition; that this list, after annual review and approval by the Board be published as the "AAZPA Animal Black List' and that AAZPA members be encouraged to support a policy of non-exhibition of such endangered forms."

\section{L. BOYLE, Chairman, IUCN Survival Service Commission.}

